\title{
Anthropological practices, inter-group conflicts and shared colonial experiences in a regional context of the Lower Amazon
}

\author{
Eliane Cantarino O'Dwyer ' \\ Katiane Silva' \\ 'Universidade Federal do Pará, Belém/PA, Brasil
}

\begin{abstract}
The purpose of this paper is to present new reflections on ethnographic research conducted in the Lower Amazon, in social situations investigated under fieldwork conditions over two and a half decades. During this period, nation-building developmental projects promoted by capitalist enterprises and the modernising state, regarded as the two most important powers that organise space today, have been implemented. In this context of hegemonic developmental policies, narratives related to territorial and cultural rights are produced, which equally count on the contribution of anthropologists through academic research and the elaboration of legal and administrative reports in Brazil as new narrative genres.
\end{abstract}

Key words: Anthropological practices, Quilombolas, Munduruku of the Santarém Plateau, Territorial rights, Power relations. 


\section{Práticas antropológicas, conflitos intergrupos e experiência colonial compartilhada em um contexto regional do Baixo Amazonas}

\section{Resumo}

O objetivo deste artigo é apresentar novas reflexões sobre pesquisas etnográficas realizadas no Baixo Amazonas, em situações sociais investigadas em condições de trabalho de campo ao longo de duas décadas e meia, nas quais são implementados projetos desenvolvimentistas de construção da nação promovidos por empreendimentos capitalistas e o estado modernizante, considerados como os dois mais importantes poderes que organizam o espaço hoje. É nesse contexto de políticas desenvolvimentistas hegemônicas que são produzidas narrativas relacionadas aos direitos territoriais e culturais, que contam igualmente com a contribuição dos antropólogos mediante pesquisas acadêmicas e na elaboração de relatórios e laudos antropológicos como novos gêneros narrativos.

Palavras-chave: Práticas Antropológicas, Quilombolas, Munduruku do Planalto, Direitos Territoriais, Relações de Poder. 


\title{
Anthropological practices, inter-group conflicts and shared colonial experiences in a regional context of the Lower Amazon
}

\author{
Eliane Cantarino O'Dwyer \\ Katiane Silva
}

\section{Introduction}

The purpose of this paper is to present new reflections on ongoing ethnographic research in the Lower Amazon, through social situations investigated under fieldwork conditions over two and a half decades'. During this period, nation-building developmental projects have been implemented, promoted by capitalist enterprises and the modernising state, regarded as the two most important powers that organise space today (Asad 1993). This modernising project of constructing the Brazilian nation-state involves not only the governing class who try to implement it, but also those who struggle with its negative effects in established legal political spaces. Thus, together with the modernising project, new ways of making history are configured, particularly after the Federal Constitution of 1988, through the recognition of lands traditionally occupied by indigenous peoples, quilombolas and other categories of traditional peoples.

It is in this context of hegemonic developmentalist policies that narratives related to territorial and cultural rights are produced, which equally count on the contribution of anthropologists through academic research and the production of "new narrative genres (such as anthropological expert reports, identification reports, environmental impact studies)" (Oliveira 2013: 48).

Thus, social identities like quilombolas, indigenous peoples and other categories of traditional peoples - riparian, fishermen, family farmers - are triggered as forms of resistance to the effects of this type of "conservative modernisation" ${ }^{2}$ that in practice, denies "original" rights and possession over areas of traditional occupation, which are, however, ensured by the Federal Constitution of 1988. Within the legal framework of civil rights, the concept of private land ownership has hitherto been prevalent over other forms of dominion (Duprat 2012). It is within this institutional framework that we exercise the anthropological task of observing and describing such encounters/clashes between the implementation of so-called developmentalist projects and the local forms of adaptation, cooperation and/or resistance to the action of these hegemonic economic and political powers.

\footnotetext{
1 Projects coordinated by Eliane Cantarino O'Dwyer: Provárzea: Socioeconomic Situation: Diagnosis of Settlement Types, Demographics and Economic Activity (2002-2005); Regularisation Project of Quilombola Territories of Western Pará, Ford Foundation (2008-2010); Ethnicity, cultural practices and forms of social organization in a regional context of the Lower Amazon, CNPq (2010-Atual), Capes-Fapespa (20162018); Intersections of ethnographic and archaeological knowledge in Lower Amazon contexts: the case of the Aiaiá territory in Santarém, Pará, Edital Universal CNPq (2014-2017). Quilombos do Trumpetas and Erepecuru-Cuminá, Study Group and Fieldwork in the Amazon, Proex-UFF (1992-2000).

2 The term "conservative modernisation" is used to refer to the modernisation of agriculture, "which has been achieved without changing the structure of rural property" and its "perverse effects": "concentration of property", "income disparities", "Rural exodus" means an "increase in the rate of labour force exploitation in agricultural activities" and "worsening quality of life of the rural working population" (Palmeira 1989: 1)
} 
The processes of change and transformation observed in ongoing research experiences, particularly in the last two decades, have given rise to new identity configurations, organisational forms and socio-environmental conflicts on an unprecedented scale.

It is in this regional context of the Lower Amazon that anthropological practices have observed and recorded the hegemony of corporate economic forces and state actions that have been imposed in the name of "progress", in the face of which traditional cultural forms have only been recognised through legal categories like indigenous, quilombolas and use of the most ambiguous and generic term of traditional peoples (Presidential Decree no. 6.040 of 02/07/2007). These traditional peoples are considered to be in contrast to modernity, such that the "traditional" denomination signals the subjection of the life of such groups to changes intended to be modernising and that are considered sources of salvation for the economy, politics and the nation-state.

Anthropological knowledge produced in this regional context of the Lower Amazon has observed and described such processes of change not only through academic production, but also through the anthropological expertise used in the recognition of the territorial rights of indigenous peoples and quilombolas ${ }^{3}$.

The legal discourse of the recognition of territorial rights participates in the construction of processes of the creation of "modern" realities that shape new social relationships in terms of legal rights, which, as observed in some ethnographic situations, have also contributed to dividing groups that self-identify as indigenous, quilombolas and other categories of traditional peoples, such as the case observed between quilombola communities on Lake Maicá and their Munduruku neighbours on the Santarém Plateau.

The notions of ethnogenesis and ethnic emergence as explanatory frameworks to describe this new social and political configuration in the Lower Amazon (Ioris 2019; Vaz Filho 2010)4, by producing relevant knowledge concerning the current identity construction of indigenous and quilombola groups, raise the risk of merely reversing the regional historiographical narrative regarding the disappearance and erasure of indigenous peoples in this region of the Amazonian frontier with positive signalling, "substantiating a process that is historical" based on the use of "naturalising metaphors" (Oliveira 1998: 62). Such metaphors are equally tributary to "another frequent classification (...) [,] that of the attribute of invisibility", which "remains partisan to an ethnology of cultural losses and absences" (Ibid.).

Thus, based on the ethnographic situations, we seek to reflect on the risks of an uncritical reproduction of legal administrative discourse by anthropologists (Asad 1991), in this case, through the division of groups and communities that contemplate ancestral relationships and common dominion that is reduced to legal administrative categories that impose the division of the territory as the only means of defence against the advance of agribusiness economic interests and projects concerning the construction of dams and ports for Brazilian Midwest soybean transhipment, like the proposed construction of the Port of Maicá.

In the ecological context of the Lower Amazon, the fields of connected activities among fishing, agriculture and cattle raising, bring together domestic groups in an environment defined by an integrated system of lakes that encompasses the floodplain and plateau communities. Thus, the new configuration of modernity that has guaranteed territorial rights of traditional peoples and communities has likewise been creating intergroup disputes over spatial boundaries in large-scale ecological units, formed by rivers, streams and lakes,

\footnotetext{
3 One example is the case of quilombola communities in Santarém (Pará) and the anthropological reports prepared for Incra/Sr-30, which were accompanied, under fieldwork conditions, by members of the quilombola associations and the Federation of Quilombola Organisations of Santarém (Federação das Organizações Quilombolas de Santarém FOQS).

4 The most recent production on the process of organising the indigenous movement in Lower Tapajós and Lower Arapiuns has been addressed in the works of Ioris $(2014,2018)$, Vaz Filho $(2013)$ and Lima $(2015,2019)$. These publications reveal the possibility of an exercise of contrastive comparison between the social and political processes in the Lower Tapajós region and those in the Ituqui-Maicá region, on the Santarém Plateau. However, this is beyond the scope of this article.
} 
especially in the region that encompasses the Ituqui-Maicá floodplain communities - the Aiaia territory, together with the Munduruku of the Santarém Plateau, which occupy the territory located between Lake Maicá and the PA 370 highway, which runs from Santarém to Curuá-Una.

It is within this regional context, comprising the Ituqui-Maicá floodplains and areas of solid ground and part of the Santarém Plateau, where the social situations are addressed and "the observed facts" and "recorded behaviours" under ethnographic fieldwork conditions constitute part of the accumulated relationships and experiences between people and groups, which configure social, historical and political processes (Bensa 1998: 46), in a range of scales beginning with the local level.

Faced with the changes arising from the implementation of developmental projects to exploit commodities, particularly soybean, which affects all the communities of Ituqui-Maicá and the Santarém Plateau, the activation of indigenous and quilombola ethnic identities for the purpose of recognising territories of traditional occupation, the prevailing feeling is still one of continuity of the socio-cultural forms of family and community organisation translated into ethnic and territorial rights.

The new narratives on rights are contextually communicated between leaders and groups to overcome the divisions and disputes recently introduced over areas of common and shared use, which raises the question whether, in the hegemonic context of modernity, individuals and groups can trace their lives free from a colonialist vision that makes the sustainability of their existences (un)sustainable.

It is within this context of the struggle for the recognition of constitutional rights (Consituição Federal, 1988) in which the "dominion of the social has been restructured and/or constituted" (Asad 1991) that makes it necessary to problematise oppositions between the modern and the traditional by focusing on social interactions within a historical perspective of hegemonic powers, including the local colonial relationships involved in this new moulding of modernity (Van der Veer 2001). This approach from the margins intends to highlight fields of interaction and historical encounters, though fragmentary, like the case of the Taperinha estate and travellers reports that indicate the existence of indigenous and slave labour in the economic exploration of the Aiaiá region.

The current differences produced in the context of the application of constitutional rights between indigenous peoples, quilombolas and other categories of traditional peoples are not constituted as cultural essences, but are the result of power relations inherited from as far back as the colonial period ${ }^{5}$, like the Taperinha estate, principally based on the ethnographic situation of the dispute for territorial boundaries between the Munduruku of the Santarém Plateau and the quilombolas of Maicá, even though these involve kinship relationships, including among their leaders.

Consequently, these are not only distinct organisational forms, but also networks of historical interaction, which force us to question the very categories with which we usually study these so-called traditional groups and peoples. Thus, we seek to explore alternative ways of analysing ethnographic problems and materials based on new narratives that present themselves as alternatives constructed by the social actors themselves - "living the way we have always lived" - to configure modes of interaction and relationships that, in practice, can be lived by them.

\footnotetext{
5 The concept of "coloniality of power" refers to a new pattern of world power, based on the "social classification of the population according to the idea of race [...], which expresses the basic experience of colonial domination and which ever since, has permeated the most important dimensions of world power, including its specific rationality, Eurocentrism. Thus, this axis has a colonial origin and character, but has proven to be more lasting and stable than the colonialism within which it was established. This implies, therefore, an element of coloniality in current hegemonic pattern of power." (Quijano, 2005: 117)
} 


\section{Aiaiá Territory and the Taperinha estate: a shared colonial experience}

In the municipality of Santarém, Pará, one of the main slaveholding properties was the Taperinha estate, which belonged to a Portuguese man with the insignia of Barão de [Baron of] Santarém, who was associated with the North American, Mr. Rhome, living in that region, along with others who immigrated there from 1867 onwards, shortly after the end of the US Civil War in 1865.

One of the ethnographic pieces of evidence of this slave relationship inscribed in the territorial space are the cavados, which comprise excavations made by slave labour. These cavados still allow the flow of water between the Ituqui River and the Maicá channel, facilitating the transportation of boats and goods in the region. For the Ituqui quilombolas, the cavados symbolically and significantly condense the "sacrifice" of ancestral work and demarcate the relationship of these groups with the territory. The production of this landscape incorporated into social relationships, since the time of slavery, is known as the Aiaiá territory (Papavero \& Overal 2011) in the narratives of the travelling naturalists who passed through it in the nineteenth and early twentieth centuries.

According to recent reports from the residents of the Ituqui quilombola communities, one of these cavados is currently called "Darlan's cavado" - the name of a farmer who claims to be a descendant of the Riker family, belonging to the former Confederates in Santarém. This cavado is located on the right bank of the Ituqui River in a floodplain area, cited by historiographical sources as "subsidiary" to the Taperinha estate during the period of slavery. Thus, the cavado can be considered an ethnographic evidence of the process of occupation that constitutes the social memory of the forms of relationships established.

Reference to this cavado is also found in historiographical sources, such as a report by the naturalist Barbosa Rodrigues concerning his visit to Taperinha in 1871: "after crossing the Cavado, I entered the Ayayá [Maicá] river, where the Hon. Mr. Barão de Santarém's estate is located [and after] a few hours of travelling on this river, I arrived at the aforementioned estate [Taperinha] at two o'clock in the morning". The "Taperinha estate" was considered by the naturalist as "the first in the municipality", directed by the "active administration" of the North American, Mr. Rhome (p. 121-122). In the book Taperinha (Papavero \& Overal 2011), in a note on the cavado, the following explanation is also given: it is an "artificial channel, following the tradition made to order by slaves of Barão de Santarém, in the western part of Ituqui Island, to reduce the navigation time. It was a kind of artificial 'opening', linking the Ituqui channel to the Maicá or Aiaiá channel” (p. 126).

Figure 1: Taperinha estate

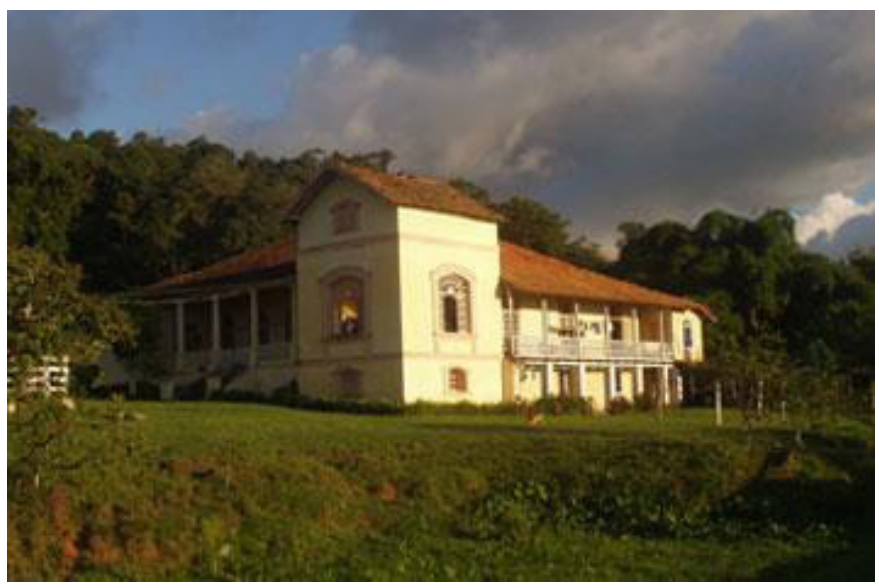

Source: (Santarém.pa.gov.br) 
In the nineteenth century, the Taperinha estate was the scene of intense activities linked to the exploitation of resources from the floodplain and solid areas, as well as scientific research. In turn, this period was recorded by visitors, commonly called naturalists, and with regard to the region under study, the records are profoundly marked by certain personalities, among the most important we have Joseph B. Steere (1870-1871), Charles F. Hartt (1870-1871), João Barbosa Rodrigues (1871) and Herbert Huntingdon Smith (1875). According to the sources consulted, these researchers were welcomed by the American family, Rhome, and in Taperinha and surrounding areas several specimens of fauna and flora were collected that became holotypes in several Brazilian and foreign collections. The records indicate the presence of members of Romulus Rhome's family and slave and Indian labour at the Taperinha estate, according to the terms used at the time, and describe it as a thriving place where tobacco and sugar cane were grown, in addition to cocoa harvesting (Papavero \& Overal 2011).

In this region of Aiaiá, so named by both riverside dwellers and Santarém farmers, the "remnants of the quilombo" communities that make up the Quilombola Maria Valentina Territory differentiate themselves and invoke their constitutional rights using, as a prevailing criterion of belonging, the presumed descendance of group members from a common ancestor named Maria Valentina Ramos, who lived near the Taperinha estate. According to Tia Gó (88 years old) - the granddaughter of Maria Valentina, who welcomed us into her home on the banks of the Ituqui River in 2010 and told the researchers, "I am quilombola" -, her grandmother was an angry old woman who was even capable of standing up to men. In her house, where she was raised, there were a lot of crops, a variety of fruits and cattle that stayed at the far end of her land. Therefore, social memory refers to Maria Valentina as a slave freed by her resistance and bravery.

In the context of fieldwork, at the presentation meetings of the team of anthropologists, like those held in the communities of São Raimundo, São José and Nova Vista that form the Valentina Territory, members of the communities present expressed their concern that due to the process of racial miscegenation among them, especially after the Cabanagem (Salles 1971), researchers questioned the use of terms like quilombo and the self-definition of quilombola, often related to the descendants of black people sold into slavery.

However, in this field concerning the application of constitutional rights, researchers gathered at the Brazilian Association of Anthropology have questioned the use of forms of identification and classification that are foreign to the social actors themselves, based on "historiographical", "archaeological", "racial", and "cultural" criteria, in search of the "meaning" considered "correct", "valid", and "true", by insisting on the comprehension of new meanings that use of terms like "remnants of quilombos" acquire in social actions guided by the existence of the constitutional device (O’Dwyer 2011).

Thus, the legal existence of a group depends on the actions and meanings that are produced in the field of recognition of the differentiated rights of citizenship, which can only be interpreted "when they are situated in a social organisation and in a praxis of communication" (Barth 1989: 85). By orienting their actions and producing meanings in these contexts, individuals and groups are driven by worldviews, representations and social relationships that shape and filter their experiences (Ibid.).

From an anthropological perspective, race exists as a "cultural construct" and "native notions of race are (considered) crucial to understanding ethnicity (...), and may be important in the extent that they inform people's actions" (Eriksen 2010: 6-7). Ethnicity as a feeling and condition of belonging to an ethnic group can thus take many forms, and ethnic ideologies tend to accentuate common descendancy among its members. This is the case of the quilombo communities that make up the Maria Valentina Territory.

During the ethnographic work conducted in 2010, through social memory - whose importance is fundamental in anthropological research, because "to be able to share another's past is to be able to participate in their present life" (Fabian 2010: 19) -, we heard reports in which the common origin of members of communities of the Ituqui region, self-identified as descendants of Maria Valentina, established the vindication of a collective territory through kinship, rather than phenotype characterised by skin colour. 
According to the reports, Maria Valentina maintained relationships with many men and had a variety of children with them, including in terms of colour, and this fact was constantly mentioned in the construction of a common origin and ethnic belonging. However, the relative "ethnic" (read phenotypic) diversity of the context in question was also related to historical events in the region, particularly the Cabanagem movement ${ }^{6}$ in the 1930s.

The great diversity found among the movement's members, called cabanos, included individuals considered 'white', of European origin, 'black', of African origin, brought over as slaves, Indians, and others considered mestizos: caboclos, indigenous and white; cafuzos, indigenous and black; mulatos, black and white (Salles, 1971).

The discussion concerning the construction of quilombola identity in the fieldwork situation is understood as and referenced to this historical origin of the communities and the common descendancy from Maria Valentina, a woman considered 'brave' and 'angry', like the insurgent cabanos.

This native theory of miscegenation dialogues with Brazilian social thinking, like the book $O$ negro no Pará (The black man in Pará) (1971) by Vicente Salles, according to whom miscegenation took place intensely in the Amazon and in the captaincy' of Pará, where the mass of the slave population in the mid-nineteenth century was no longer exclusively black, with the exception of native Africans, resulting in the 'crioulo' [lit. creole], a term used in Brazil to refer to any black person, to multiple ethnic combinations. The mestizos that formed the so-called "coloured population" were also slaves, according to an announcement published in the press of the captaincy of Pará regarding the escape of a "mulato atapuiado", a mulatto who also had indigenous phenotypic characteristics (Ibid.).

Miscegenation did not mean the elimination of prejudice, which was considered one of the causes "that set the 'caboclo' mass on the warpath during the Cabanagem against the reinóis" (Salles 1971: 138), as those born in the kingdom of Portugal were called. This designation also extended to those not specifically Portuguese, "who were identified through economic interests and common social positions" (Ibid.). Some authors have even identified the "Cabanagem as a kind of racial struggle" against prejudice (Ibid.).

Again, according to Vicente Salles, in the Cabanagem "the black man who had thus far fled to distant mocambos [refuges of runaway slaves generally located in the forest], joined the movement en masse, intent on achieving freedom" (Idem: 212). However, this was not granted to him and after the Cabanagem, the mocambos multiplied throughout most of the Amazon.

Nowadays, studies on the formation of political identities have been characteristic of "modern societies". According to Eriksen (2010: 85):

While many historians tend to try to find out what really happened - some even distinguish between 'invented' traditions and 'real' traditions (Hobsbawm, 1983; cf. chapter 5) - most anthropologists would rather concentrate on showing the ways in which particular historical accounts are used as tools in the contemporary creation of identities and in politics. Anthropologists would stress that history is not a product of the past but a response to requirements of the present. For that reason, this discussion of history relates not to the past but to the present.

\footnotetext{
6 The Cabanagem was a rebellion that occurred in the province of Pará, from 1835 to 1840. Although for different causes, the cabanos (mostly Indians and mestizos) and members of the local elite (traders and farmers) united against the regency government in this revolt. The main objective was to conquer the independence of the province of Grão-Pará during a period of rupture and following the independence of Brazil. The cabanos intended to achieve better living conditions, while the farmers and traders who led the revolt sought greater participation in the administrative and political decisions of the province. According to Harris (2017), the movement's leaders called themselves "defenders of the homeland and of freedom".

7 Captaincies were administrative divisions of the former overseas territories of the Spanish and Portuguese Empires.
} 
According to reports collected in the field, Maria Valentina became a slave in her childhood and a genealogical survey indicates she was born between 1860 and 1865 , making her a contemporary of the arrival of the Confederates in Santarém after the American civil war. In Gerald Horne's The Distant South (2010), on the Confederates in Brazil in 1867, two years after the end of the American Civil War, the New York Times reported that several southern farmers had moved to Brazil and settled there. The persistence of African slavery in Latin America, especially in Brazil, even after its extinction in North America, continued to provide a basis for the descendants of the slaveholding southern Confederates and their allies.

In 1885 , three years before the abolition of slavery in Brazil in 1888, the US Consul in Pará had noted the disillusion of his former compatriots with miscegenation. The Confederate project in Brazil was considered a disaster precisely due to the interracial relationships prevalent in the tropics. Thus, many American Confederates who defended the ideology of segregation returned to live in the USA (Horne 2010).

Figure 2: resident of the margins of the Maicá

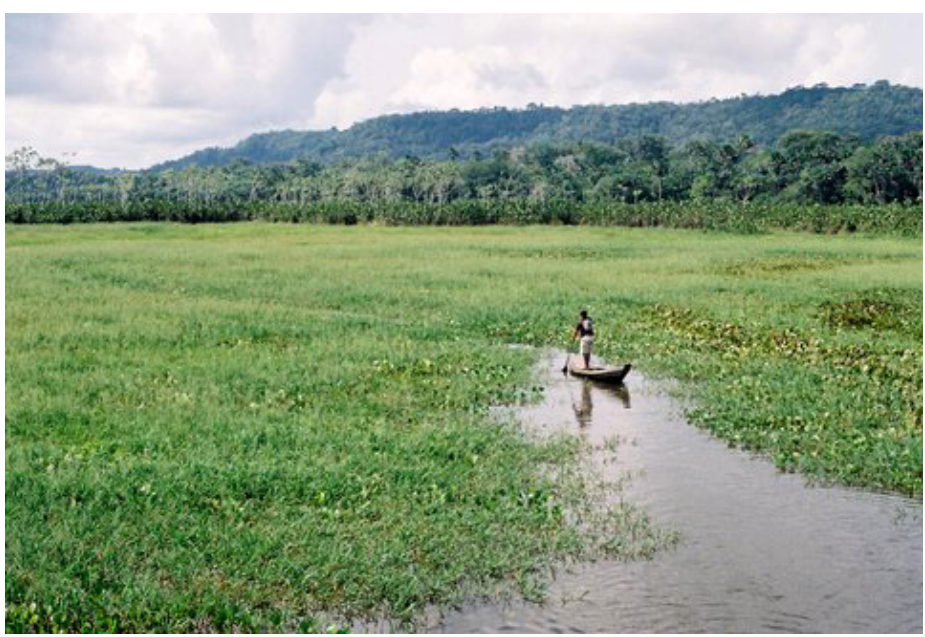

Source: Elisa Cotta de Araújo, 2010.

The quilombolas who identify themselves as descendants of Maria Valentina are currently constructing the political project of collective title of the territories they occupy as a means of fighting for the autonomy of ways of making, creating and living, and against other models of spatial organisation and the exercise of power.

This ethnographic narrative on the Ituqui-Maicá quilombolas, the Aiaiá territory, has another empirical variant in the case of the Trombetas and Erepecuru-Cuminã quilombos, which used events present in social memory related to heroic legends and mythical narratives concerning the great snake of Barracão de Pedra, in the contexts of affirming their identity as historical subjects derived from the quilombos (O'Dwyer 2000).

Thus, groups self-identifying as quilombo remnants in the relations they establish with the Brazilian state create different ways of belonging to the nation, as an imagined community, like the case in question, that reconfigure ethnic identities by associating gender and ethnicity to the processes of construction of the nation. In the ethnographic situation of the quilombola territory Maria Valentina, the diacritic sign referenced to the female gender by the miscegenation promoted by a black woman who had many children from the sexual relations she engaged in with many men of various ethnic and national origins, produces an inverted image of the role of the woman and mother symbolically attributed by the nation-state, which subverts structures of the domination historically imposed upon them (O’Dwyer 2016). 


\section{The Munduruku of the Santarém Plateau: the struggle for territorial recognition in the context of agribusiness expansion in Santarém}

According to their own name, the Munduruku do Planalto ${ }^{8}$ are located in an area of the Santarém Plateau that encompasses Maicá Lake. The area they occupy is located between the Santarém-Curuá-Una state highway, PA 370, and the banks of Maicá. This territory is composed of four villages, Açaizal, Ipaupixuna, São Francisco da Cavada and Amparador, where they develop agricultural and fishing activities, animal husbandry and provide services on surrounding farms.

The region is also inhabited by self-identified quilombola communities, some of which have kinship and affinity ties with the Munduruku, with whom they establish relationships marked by intergroup alliances and conflicts, often fostered by a shared colonial history and its power structures present throughout local history. Thus, producing ethnographic material concerning the social changes and struggles of indigenous collectives, quilombolas and traditional peoples in a context circumscribed by the advance of various fronts of colonisation and the exploitation of natural resources, implies great care regarding information and attention when problematising the various circumstances in which these power structures are rearranged in the most diverse social segments involved in the situations.

The prevalent territorial conflicts, both for the Munduruku of the Plateau and the quilombolas on the banks of the Ituqui-Maicá, are related to the expansion of soybean cultivation along the Cuiabá-Santarém highway, BR-163, and the project to construct the Port of Maicá for commodity outflow. Using a narrative based on the idea of "development", "civilisation" of the region and of "bringing progress", and through continued expropriation, these new economic-entrepreneurial agents are forcing the reorganisation of social relationships, including the intensification of tensions between and within groups and socio-environmental conflicts, in order to exploit and appropriate renewable environmental resources. This is an expansion front of agribusiness over the territories of traditional occupation, vindicated as indigenous lands and quilombolas by the collective subjects who fight for their recognition, demarcation and title with the Brazilian state.

In June 2018, during a field trip to the Santarém Plateau', we were able to interview some Munduruku leaders fighting for the demarcation of an indigenous land as opposed to the process of territorial expropriation that advances over their traditionally occupied spaces, forced on them by agribusiness. The leaders brought a general overview of these confrontations to the discussion, synthetically categorised here as three interconnected aspects: a) the urgency of land regularisation and the demarcation of an Indigenous Land, demanded by the Munduruku of the Plateau; b) the damage caused by the advance of soybean cultivation to the health of indigenous people, quilombolas and the environment; c) territorial overlaps in lands traditionally occupied by the Indians and quilombolas; in this case, the overlaps between the indigenous land claim and the quilombola territories of Murumuru, Murumurutuba and Tinigu, already pursuing the title process.

Between 2010 and 2015, the Munduruku leaders, in partnership with the New Social Cartography of the Amazon Project (Projeto Nova Cartografia Social da Amazônia, PNCSA) and the Pastoral Land Commission (CPT), conducted a self-demarcation study that produced a fascicule, with a map that indicates the main difficulties and conflicts engendered in the region since the arrival of agribusiness (Almeida et al 2015). The territory that circumscribes self-demarcation is mostly superimposed on the Ituqui Federal Gleba ${ }^{10}$ and, to a lesser extent,

\footnotetext{
8 The ethnonym Munduruku covers self-identified indigenous groups in various contexts of interaction, such as the Munduruku of the Middle and Upper Tapajós (Loures 2018) and the Munduruku of the Santarém Plateau. This ethnonym of the colonial period is updated in the vindication of territorial and cultural rights against the Brazilian state. For the different ethno-social meanings of an ethnonym, see Bazin (2017).

9 Within the scope of the Ethnicity, Cultural Practices and Forms of Social Organisation Project in a Regional Context of the Lower Amazon, coordinated by researcher Eliane Cantarino O'Dwyer, developed between 2016 and 2018, with funding granted by CAPES-FAPESPA 005/2015.

10 The definition of gleba (rural or urban) is related to parcels of land that have not yet been allotted or divided and allocated (Lago 2017) On notions of land, territory and traditional peoples, see respectively Almeida (2008), Oliveira (2012), O'Dwyer (2013).
} 
the Belterra A Concession Federal Gleba. Only the former is completely blocked for land regularisation purposes, due to a request made by the National Indian Foundation (FUNAI) to the National Institute of Colonisation and Agrarian Reform (Incra) and the extinct Terra Legal Programme, based on the demand for demarcation of an indigenous land on the site. The blockade prevents the declaration of title of the area until the FUNAI has completed the land identification and delimitation process, but this does not mean that the conflicts are frozen.

Since the first half of the 200os, the Munduruku have been engaged in a movement for the recognition of their ethnic identity, provoking the FUNAI to conduct studies to identify the indigenous territory. In 2012, the FUNAI conducted the first study, the preliminary qualification of the territory under claim, but did not expedite the necessary measures for a deeper study on the historical and social situation of the region.

In one of the documents produced by the Munduruku, sent to the Public Prosecutor's Office (MPF) on October 2012, and used to support the Public Civil Action of the MPF on May 29, 2018, the following threats to the territory were recorded: siltation and contamination (by pesticides used in soybean cultivation) of the Açaizal stream; contamination and death of animals; air contamination (through spraying poisonous pesticides); pressure from farmers involving harassment over land purchases and land grabbing by "fencing off villages"; deforestation for soybean planting; impeding spatial mobility and obstructing the right to free movement by building fences and guarding arbitrary boundaries; together with the systematic destruction of areas considered archaeological sites (Ministério Público Federal 2018).

According to indigenous reports, there are occasions when discrimination occurs at the institutional level, as in the case of certain Special Secretariat of Indigenous Health (SESAI) officials who refuse to serve them because they are not "regularised Indians" and are not part of a state-demarcated territory.

In addition to these discriminations, one of the major problems that commands the attention of the Munduruku is the indiscriminate use of pesticides in the region. They denounced the use of pesticides that have caused problems of respiratory failure and are banned in Brazil. According to the Indians, a representative of the Guamá-Tocantins Indigenous Special Health District Basic Healthcare Unit, where they are attended, verified the prevalence of respiratory problems and allergic crises among indigenous children and adults, as well as other problems that include diarrhoea, intestinal diseases and outbreaks of leishmaniosis.

The expansion of the agricultural frontier is well remembered by the interlocutors since grain transhipment occurs through the port constructed by the Cargill company between 2001 and 2002, and along the BR-163 highway. From then on, for about 10 years, the various groups and territories traditionally occupied in the Plateau have been under pressure from agribusiness entrepreneurs. These pressures materialise, for example, in cases where Indians, quilombolas, family farmers, and other categories of traditional peoples, are mobilised by farmers to serve as labour in exchange for remaining in the location.

One of the major developments that poses a threat to the Indians and quilombolas is the pressure to build the Port of Maicá, which is to be located on the lake of the same name. The Brazilian Port Company of Santarém (Embraps) has headed this process and since 2013, they have been involved in clashes with local leaders to execute the construction of this venture. Initially, Embraps hired the Research Support and Development Foundation (Fundação de Amparo e Desenvolvimento da Pesquisa, FADESP) to elaborate the Environmental Impact Study/Environmental Impact Report (EIA/RIMA).

In the following year, Embraps was considered fit by the regulatory agency and the National Waterway Transportation Agency (Agencia Nacional de Transportes Aquaviários, ANTAQ), which sanctions the construction of the Port of Maicá. In 2015, the Secretary of State for Environment and Sustainability (SEMAS) published an EIA/RIMA favourable to the construction of this port. In 2016, in opposition to this decision, the Federation of Quilombola Organisations of Santarém (FOQS) questioned the MPF and SEMAS regarding the environmental studies conducted by the FADESP. Thus, under pressure from the social movements, in March 2016, the SEMAS held a meeting to inform the communities involved regarding the project of the Private Use Terminal on 
Maicá Lake. Faced with the onslaught of agribusiness interests, numerous social groups opposed the progress of construction. Among the groups mobilising against the construction of the port, the collective of indigenous women and quilombolas should be highlighted. Later, the Federal Court ordered the suspension of the licensing for the Port of Maicá and the Regional Federal Court of the First Region denied Embraps' appeal (Del Arco 2017).

According to the Indians of Açaizal village, the organisation and mobilisation of the region's domestic groups, whether indigenous or quilombola, is a form of resistance against the "colonising project" of the Amazon, which has tolerated violence, both physical and symbolic, regarding constituent elements of the "domestication" and exploitation of the region studied.

In outlining the local transformations linked to a global Amazon exploration project, the Munduruku emphasise that prior to the 200os, there was no concern among the Indians regarding the imminent destruction of the forest, since the Plateau area was occupied by "us and a few owners". However, from the moment that "the large sojeiros [soybean agribusiness owners] began to occupy and take possession of our territory, they began to prevent us from using this territory that has always been ours".

According to the Munduruku, the process of change in the local landscape, with the replacement of native forests by soybean and corn, has concrete and immediate implications in their lives: "because what was natural for us to use (the territory) began to be restricted. (...) Then we began to realise that something was wrong, the use that was ours, that was always ours, for some reason ended up being restricted from our lives". For this indigenous people, the "only way out", the only way to stop or combat the onslaught of the farmers was through social organisation:

We began to create our own indigenous peoples' associations because we could see that the pressure was coming and we had to defend ourselves somehow. During these years, we had great clashes, real confrontations: we stopped tractors, we denounced irregularities and the destruction of archaeological sites, silting the streams... through all this, the pressure comes very quickly and we end up having to do something, otherwise we end up being suffocated by this action and trampled on by these large ventures. (Interview with Munduruku leaders, June 2018)

Further, according to the reports by the Munduruku during ethnographic fieldwork:

Even with our quilombola relatives and brothers, we had a conflict that we ended up resolving after discussions, because there was an overlap. We reached a consensus and now they're brothers in the struggle who can help us and we can help them. While we were arguing among ourselves, the sojeiros took advantage and ended up infiltrating ideas (contrary to demarcation) among our people. We know we're brothers, but legally, we need this delimitation. And today, we assume that everything is united and when the quilombola needs our support we're there, and when we need them, they're there to support us. (Interview with indigenous leaders of the Açaizal village, June 2018).

The Munduruku leaders reported that conflicts between the Murumuru quilombola community and the indigenous village of Amparador, and between the Ipaupixuna and Açaizal villages and the Tiningu quilombola community were partly resolved. Due to the agreements, the Tiningu and Murumuru Technical Identification and Delimitation Reports (RTID) were published. Negotiations are still pending between the Murumurutuba quilombola community and the São Francisco da Cavada village, but note that the proposal has advanced.

Although the indigenous leaders claimed that they were not properly informed about the onset of the process of territorial recognition of quilombola communities, prior to 2010, based on the negotiations during the period of contestation of the recognition studies of quilombo lands, it was possible to conclude that these form part of the common use territories, currently under dispute for demarcation. 
Such intergroup conflicts have also contributed to the advance of land grabbing, as some Munduruku leaders acknowledge. The attempt to incorporate Indians and quilombolas within the logic of employer domination strengthened the prejudice and racism against Indians and quilombolas themselves and facilitated the process of territorial expropriation.

Negotiations concerning the division of these traditionally occupied territories advanced between the parties and in 2015, the MPF recommended "that within a maximum of 45 (forty-five) days, the President of the National Indian Foundation (FUNAI) take the necessary steps to constitute the multidisciplinary Technical Group (TG) that will conduct identification and delimitation studies for the indigenous territory of the Munduruku of the Santarém Plateau" (OFÍCIO/PRM/STM №, of November 18, 2015).

In an interview with an indigenous leader of the Ipaupixuna village, it is possible to observe the urgent need for the creation of the TG:

We've been in this fight for 11 years. During this period of 11 years, we've suffered great threats, and the deforestation continues. And now, with this whole situation, it will never end. Not just with the sojeiros. In the area of lakes, there's also a lot of this issue of predatory fishing. (...)

We see around here that there's not even a minimum of respect for our ethnicity. It's always been like this, this thing of: "ah, there's no such things as Indians, there's no quilombolas". I think it is the gaucho" who should not exist inside this area. Because their land is very far from here. So, we live within this conjuncture, this very difficult moment, because there is great concern. (...) Intimidation leads to murders and we really need this working group. (Interview with Munduruku leaders, June 2018).

The categories of sojeiro and gaucho often represent the same group: large landowners who plant soybeans and who, for the Indians, cause the destruction of the environment and the consequent production of social suffering materialised in threats. The intimidation suffered by Indians and quilombolas occurs in various spaces. The year 2018 was extremely troubled for these collectives, because of the presidential elections, as the major soybean producers aligned themselves with one of the presidential candidates who publicly stated that "not one inch will be demarcated for indigenous reserves or for quilombolas" in his pre-election campaign.

In January 2018, a meeting was held in Açaizal village, organised by the MPF, to discuss the issue of land regularisation and environmental crimes. According to reports of the Indians, the president of the Santarém Rural Union and several allies attended the meeting and created turmoil. At the time, one of the sojeiros' lawyers made the following statement: "I recognise you as Brazilian citizens, but Indians you have to prove to me! Is this Indian?"

The Munduruku, previously recognised by travelling naturalists when describing the landscape of the Aiaiá territory, currently suffer two forms of prejudice: on the one hand, due to their ethnic status as indigenous, and on the other, they are accused of being "fake Indians" because they no longer speak the Munduruku language. However, this "absolute competence" has long been recognised by linguists as "myth or fallacy" (Figueiredo 2011: 68), especially in the regional context of the Lower Amazon immersed in power relations inherited from the colonial period.

11 This term is widely used by local Amazonian populations to refer to migrants from the south of the country, who have settled on the margins of the federal and state highways established since the 1970s. The designation gaucho marks not only the geographical distance between northern and southern Brazil, but very different cultural practices in the appropriation and use of territory. 


\section{Networks of Historical Interactions}

On the basis of the Taperinha estate, the presence of American Confederates in Santarém allows us "to lay out fields of historical interaction and encounter, however fragmentary" (Van der Veer, 2001), such as the distinctions between the ethnic categories of Indians and slaves that emerge in the reports of travelling naturalists concerning the labour force on the Taperinha estate. According to the letters written by the naturalist J. B. Steere in 1871 :

The hands, Indians and slaves, were cleaning off the logs and brush from new land and planting tobacco and the thorough way in which they did their work showed that their master was trained in a more thorough school of farming than is found in this country. (Steere 1871, apud Papavero et al. 2008: 139)

Moreover, according to this travelling naturalist, Indians and slaves were equally destined to perform specific tasks, with the Indians skilled in "gathering the different kinds" of wood and proceeding with the collection of Brazil nuts taken to Santarém along the river "from whence they are shipped to Para [Belém], and thence to foreign ports" (Steere 1871, apud Papavero et al. 2008: 141).

A few years later, in 1879, Herbert Huntingdon Smith, another travelling naturalist visiting the Taperinha estate, the "joint property of Mr. Rhome and the Baron of Santarem", describes work in which "half a dozen stalwart negroes are employed in 'feeding' the great cane-mill, and carrying away the refuse" (Smith 1879: 153). Both accounts of these naturalists seem to presuppose a certain type of skill specialisation, between Indians and blacks, in commercial agricultural production in the slave trade circuit, with which the Confederate colonies were associated in Brazil, like that in Santarém, with a view to the "revival of southern society" (Silva 2011) in a region of the Amazon.

Family work on farms through the division of tasks according to gender and age is further described by Smith when he mentions the activities observed:

Fifteen or twenty men and women are employed here in preparing tobacco by the Amazonian process (...). The leaves are picked from the stalks one by one, as they are large enough; slightly dried for a day or two, under shelter, and brought to the house in great baskets. Here the midrib is removed by boys and women and the leaves - two, four or eight pounds together - are spread out in layers, one over the other, rolled together, and bonded with strips of bark. Next, the roll is wound tightly with heavy cord, as thread is wound on a spool; the strongest workmen are chosen for this part of the process, and one of them can wind no more than fifteen or sixteen molhos in a day, twisting the roll with his hands, while the cord, throw about a post, is held tightly with the foot. In this manner the tobacco is very strongly compressed. (Smith $1879: 157-158$ )

In the last stage of tobacco fabrication, a few pages later, and with the racial stigmata characteristic of the slave-like perspective, Smith notes:

A dozen or more women, preparing tobacco on the piazza, form a group the like of which would be utterly impossible at the north [US]; and yet I could no more analyze the scene than I can describe one of the cocoanutpalms outside; I see here only a number of decidedly ugly faces and black or brown arms, with not overclean sacks and skirts. (Smith 1879: 158-159)

In these fragmented historical narratives about Taperinha, two passages written by Smith about the daily life observed on the estate should be highlighted: 
One evening, Mr. Rhome arranges a rustic dance among the people. It begins in the orthodox Amazonian way, with a singing prayer-meeting in the little chapel, to which worshippers are called by the monotonous beat of a great drum. Then, when the concluding Pai-Nosso is sung, and the saint's girdle is kissed, the leader turns master of ceremonies, and such nondescript dances follow as could only originate in the fertile brain of a negro. There is an indescribable mingling of weird and comic in the scene: the dark faces and arms, set off by the white dresses; the octogenarian negro, striking his tambourine with a trembling hand; the half-naked babies, tumbling about under the feet of the dancers; the dim, flaring lamps, half lighting, half obscuring the moving figures. We sit and watch them until midnight, and then go away as one goes away from a theatre, dropping out of dream-life into the dark street. (Smith 1879: 160-161)

Again, according to Smith, as he had done at the festa de santo and drumming dance party, Mr. Rhome acted as cicerone to ensure "Every-day life at Taperinha gets its dash of the forest", thus it was Mr. Rhome who incidentally introduced the traveller to the regional fauna, by asking, "Have you ever seen a tapir?" - the animal had been killed the day before and pieces of its meat had been served for breakfast. Hence, "the Indians bring deer, sometimes, and wild hogs, and cotias, and pacas; Mr. Rhome shows us the skins of half a dozen jaguars and puma which have been shot about the estate" (emphasis added). According to the travelling author's comment:

One might hastily infer that the forest is crowded with game (...); but in point of fact the hunters often search for hours, without seeing so much as a monkey or a squirrel. The provision houses are the lowland lakes and channels. We can go out any evening with the fishermen, who supply not only the proprietor's table, but the people of the estate. (Smith 1879: 162-163)

This "shared colonial history" in the dichotomisation between Indians and blacks on the Taperinha estate, within the context of enslavement, each specialised, respectively, in the extractive activities of logging, and hunting and fishing; much like in the fields of tobacco, sugar cane, and working in the mills and stills, they seem to be updated in the present by dividing the territories of traditional occupation, recognised by the state as indigenous or quilombola lands.

The current process of the recognition of Munduruku lands and quilombos by the Brazilian state has also provoked intergroup conflicts due to partial overlaps between the territories of the quilombo communities on the banks of the Maicá and the villages of the Munduruku of the Santarém Plateau, which were promptly negotiated, particularly in the case involving the Munduruku village Ipaupixuna and the Tiningu quilombola community.

Both toponyms maintain continuity with the names of places that have existed since the nineteenth century on and around the Taperinha estate. When describing the archaeological site of the Taperinha mountain range for the first time, in the section entitled "Taperinha e os sítios dos moradores dos altos" [Taperinha and the sites of the residents of the highlands], Hartt mentions the fertility of the highlands in his 1885 work:

The civilised Indians who have cultivated the black earth of Taperinha and Pá-Pixuna [present day Ipaupixuna], established their residences at the foot of the escarpment, since it is a convenient place, especially for the supply of water. As expected, these ancient sites were cultivated in recent times [1870] (...). Mr. Rhome informed me that in a place called Tiningu-grande [present day Tiningu], about a league above Mr. Wallace's farm, there are signs of a very large settlement. (...) At the Taperinha estate, I was informed by an Indian that there is a tradition that the residents of the highlands were the bravest in the country, who having no canoes, crossed the Ayayá on tree trunks (...). [Thus], one might ask whether the inhabitants of the highlands were the Mundurucús [of the nineteenth century]. (Hartt 1870, apud Papavero \& Overal 2011: 108) 
The shared colonial experience between Munduruku and quilombolas as a captive labour force on the Taperinha estate and their resistance and protagonism on the margins of the enslaving, agro-exporting power, results in the relative autonomy of these groups in the occupation of territories, including shared common use areas in the former surroundings of the Taperinha estate in the region of Maicá-Ituqui, also known as the Aiaiá territory.

Consequently, regarding the construction, whether conscious or not, of these collective identities today, such as the remnants of quilombo or quilombolas and Indians who vindicate the collective title of their lands, we can say, as per Eriksen (2001: 66), that "nothing comes out of nothing". It is therefore of no use to situate these political identities in a universalist construct, since they change historically and vary geographically; nor is it of any use to situate them within the sovereignty of the state by imposing ethnic categories, but rather in the social life where individuals and groups attribute meaning to the world.

Thus, the agency of ethnic identities, indigenous and quilombola, defined from the colonial experience shared by rules imposed by the slave regime are reversed and re-appropriated by the social actors in the present, creating "new spaces of freedom" (Fassin 2010: 284) ${ }^{12}$ in the regional context of the Lower Amazon.

\section{Ethnic identities and new power relations}

At the present time, the political reconfiguration of ethnic identities - indigenous and quilombola as territorial collectives that resist the advancement of economic exploitation on renewable environmental resources in territories of traditional occupation has generated intense conflicts, some of them inscribed in the public space and in local political action, as occurred in the Tiningu quilombola community, on the shores of Maicá Lake, and the indigenous villages of the Munduruku of the Santerém Plateau. Both conflicts impose themselves as empirical evidence of a broader political context of resistance to agribusiness expansion within the regional scale in which they are situated.

Particularly following the 2018 presidential election, which was preceded by a context of uncertainties and political confrontations that ended in the impeachment of President Dilma Rousseff, the result of the last election entails a paralysis of the policies of the recognition of indigenous and quilombola lands with constant violations of the cultural rights protected by the Federal Constitution of 1988. Currently, we are observing the flexibilisation of environmental legislation and control, together with authorised political incentive on an unprecedented scale regarding deforestation, land grabbing and ecosystem destruction through the advancement of agribusiness over forest areas and Amazon river systems.

Thus, the two cases presented below allow us to relate a variation in the scale of analysis between the local and national levels, and to problematise essentialised categories by focusing on social and political experiences from the margins within an "interactive" and historical perspective.

1. The murder of the leader of the Tiningu quilombola

The processes of expropriation of traditionally occupied territories are embodied in the situation of territorial conflict in the Tiningu community, initiated in 2017, through the clearing of certain areas, the prevention of access to water, the destruction crops and contamination by pesticides, with the tragic outcome of the murder of a quilombola on September 29, 2018.

12 Regarding political subjectivation, see Fassin (2010). 
The background to this conflict involved several lawsuits filed with the MPF, MPE and complaints made to INCRA, and in February 2018, the Agrarian Court granted an injunction prohibiting the closure of the community's water supply system; and a ban on the felling of trees or vegetation of any kind that involves environmental devastation in the area. Despite these determinations, the conflict continued to intensify and seven months later the quilombola leader was murdered.

From the point of view of the quilombolas, this murder is a sign of the progress of violence in quilombola territories in western Pará and the growing pressure of businessmen and farmers regarding traditionally occupied territories.

Tiningu is one of the twelve quilombos of Santarém and its Technical Report on Identification and Delimitation was published in 2015 by INCRA. However, this murder is not an isolated fact. During the same period, another quilombola leader was murdered in the municipality of Óbidos and others are still being threatened.

In a story published on a local newspaper's website, the quilombola identity of the victim was questioned and the public debate has shifted from the violence of the murder to fraud in the recognition of the "alleged" Tiningu quilombo by INCRA, according to the website.

The question of "ethnic fraud" has been seized on by the Santarém Rural Union (SIRSAN), which represents large local landowners and agribusiness entrepreneurs. The text published on the site also includes the terms "ethnogenic conversion" and "ethnicising social engineering" as responsible for the "transformation of mestizo populations into self-declared indigenous or quilombola groups". From the perspective of SIRSAN, the policy of recognising indigenous and quilombo lands aims to attack so-called productive enterprises and areas of "private property" in the Lower Amazon region.

In response, the Federation of Quilombola Organisations of Santarém (FOQS) published a note of repudiation from the quilombola communities, "publicly expressing their deep indignation". In this note, they reaffirm the historical existence of the quilombos of Santarém by saying that "those who arrived later are the farmers and businessmen who do not live in the territories, who exploit nature and promote the devastation of our forests through deforestation, the destruction of igapós, extensive soybean planting, pollution by pesticides, [and] improper breeding of cattle and buffalo in a floodplain area". They further argue that "in our traditional agriculture, we preserve nature and our territory. Quilombolas, indigenous people and traditional peoples, are the true groups that preserve nature".

The accusations of "ethnic fraud" against Indians and quilombolas claiming recognition of territorial rights granted by the Brazilian state have been used in the political debate since the Parliamentary Committee of Inquiry of FUNAI and INCRA, instituted in November 2015 by the National Congress and conducted by the Frente Parlamentar da Agropecuária [Agribusiness Parliamentary Front] against the demarcation processes of traditionally occupied lands.

Use of the term "ethnic fraud" related to miscegenation refers to a theoretical problem that has already been scientifically surpassed, marked by nineteenth-century biology, in which linking groups to their presumed origins does not exempt them from racism (Amselle 2001). Instead of focusing on a historical production of identities and societies endowed with an agency regarding the circulation and re-appropriation of enunciates, by vindicating categories like indigenous and quilombola in the production of ethnicities and ethnic and social belonging to defend cultural and territorial rights ${ }^{13}$.

13 "The coloniality of power based on the imposition of the idea of race [has been used] as an instrument of domination ... (it is considered) a limiting factor in these nation-state building processes" (Quijano 2005: 136) 
This supposed nineteenth-century racialist scientific anthropology is heir to the colonial enterprise, imposing a classificatory logic founded on an ethnic-colonial divide, following an imposed race policy, as occurred on the Taperinha estate in Santarém, which divided labour into Indians and blacks for the purposes of forced labour.

2. Visit by the Inter-American Commission on Human Rights to the Açaizal village of the Munduruku of the Santarém Plateau

In 2017, with the purpose of "observing the human rights situation in the country," members of the InterAmerican Commission on Human Rights (IACHR) visited several Brazilian cities and communities, at the invitation of the Brazilian state. In its final report, the Commission noted that it had received "extensive information from the indigenous peoples of Açaizal, in Santarém, Pará State, concerning the pollution of rivers, waters and underground aquifers due to the indiscriminate use of pesticides and other chemicals" (IACHR 2018:7). This information was verified in loco. The meeting with Indians and quilombolas of Santarém was held in November 2018 in the Açaizal village, on the Santarém Plateau, with the purpose of listening to the testimonies and recording the conflicting situations that have occurred in the region.

On the day of the meeting, before it even began, the members of the Commission (IACHR), the leaders present, members of the indigenous and quilombola communities of Santarém and non-governmental organisations were surprised by the arrival of a group from the Santarém Rural Union (SIRSAN), who began questioning the members of the Commission. The purpose of the representatives of the sojeiros, according to reports, was to prevent the meeting from being held. To this end, according to a video released about the visit, they resorted to all manner of intimidation: photographing the license plates of the vehicles parked near the village hall and questioning the presence of the Inter-American Commission, through mock interrogation, as if they were vested with police authority. They then approached one of the members of the Commission arguing that ILO Convention 169 was a mistake and, once again, made accusations regarding the Indians, claiming that "no Indians existed" there.

Those present responded to the arrival of the sojeiros by demanding that they leave the meeting place. One of the strongest moments of conflict of this episode was the aggression suffered by an indigenous woman, who was video recording the situation on a cell phone. Only after the arrival of the police, did the group of sojeiros finally withdraw and the programme of the meeting began. Following the discussions, the interpreter of the Inter-American Commission finalised the discussions reaffirming the IACHR's commitment to follow up on situations of violation of human rights. He also pointed out the perplexity of the members as they had also participated in a conflicting situation: "We were able to see personally the kind of threats and intimidation you suffer. (...) We will formulate a report that will contain what we saw. (...) This report makes recommendations to the Brazilian state to comply with its international obligations". Another highlight in the speech was about Brazil's obligations to enforce human rights as a member of the Organisation of American States: "these recommendations are for the Brazilian state as a whole. Thus, whether or not the government changes, it has to comply with the international obligations that have been assumed".

Both situations record the occurrence of human rights violations through threats, murders and environmental crimes, also characterised by the devastation of forest areas and the pollution of water resources through the indiscriminate use of pesticides. These different aspects of deterioration of the environment and social relationships, observed and denounced by the Indians and quilombolas at the present time, represent a risk to the reproduction of their cultural practices and ways of doing, creating and living typical of traditional peoples. 


\section{Final considerations: the risk of entropy}

Less than a year after the visit of the IACHR to Santarém, major forest fires in the Amazon are being reported in the national and international news. On BR 163, the main route of soybean transhipment from the Midwest to the ports of Miritituba and Santarém in Pará, which crosses one of the most resource-rich regions in the country, there has been an explosion of fire outbreaks registered by the National Institute for Space Research (INPE). Forest fires of criminal origin, according to press reports, were orchestrated in Altamira, Transamazônica, and Novo Progresso, BR 163, by "rural producers, traders and land grabbers" ${ }^{14}$, aimed at opening up new areas for commodity advancement.

The systematic destruction of the Amazon, considered one of the last frontiers "which stands between humanity and an uninhabitable planet" (Ryan Grim, 2019) ${ }^{15}$, rings out like a catastrophic signal. According to the article:

Beginning with the military dictatorship in Brazil, when agribusiness was fully empowered, roughly a fifth of the jungle was destroyed by the mid-20oos. If the Amazon loses another fifth of its mass, it is at risk of a phenomenon known as dieback, where the forest becomes so dry that a vicious, cascading cycle takes over, and it becomes, as Zaitchik writes, "beyond the reach of any subsequent human intervention or regret".

In this apocalyptic scenario, the notion of "captivity of the Beast", developed by Velho (1995) from a field research experience in the Amazon, which began in the 1970s, references the notion of captivity, highlighting the biblical origin of the notion ${ }^{16}$, and could serve as inspiration when reflecting on the alternatives constructed by these ethnic and social groups, faced with the hegemonic advance of agribusiness, as a means of guaranteeing their own ways of doing, creating and living versus other models of spatial occupation and the exercise of power.

However, the risk of entropy in the current political context ${ }^{17}$ is real and affects not only renewable forest and aquifer resources, but also the social existence of traditional peoples and the recognition of cultural differences (Pereira 2002), guaranteed by the Brazilian state in the Federal Constitution of 1988.

The process of the systematic destruction of the Amazon rainforest is experienced as an imminent risk, by indigenous people, quilombolas and other categories of traditional peoples, of "becoming nothing" through the gradual precariousness of their livelihoods and the threat of loss of knowledge and cultural traditions.

Finally, within the winds of authoritarianism blown in from outside and celebrated within Brazilian society, like them, and even us, we can resist to live the life that can be lived in practice.

Received: September 03, 2019

Approved: October 18, 2019

Translated by: Philip Sidney Pacheco Badiz

\footnotetext{
14 According to an article published on the website of Revista Globo Rural, on August 25, 2019. Source: https://revistagloborural.globo. com/Noticias/noticia/2019/08/grupo-usou-whatsapp-para-convocar-dia-do-fogo-no-para.html

15 The Intercept, source: https://theintercept.com/2019/08/27/amazon-rainforest-fire-blackstone/

16 See also Oliveira (1996).

17 He risk of entropy can also be expressed by the concepts of ethnocide and genocide: "It is permissible to speak of ethnocide, understood as a political process imposed on one or several ethnic groups and that comprises cultural and linguistic "disintegration" that can, but does not necessarily, imply physical destruction, and develops in contexts of extreme violence or alleged cordiality. The process of ethnocide can assume more serious contours, which can be configured as genocide, taken as racial and ethnic hatred committed against specific groups, structured as an action that erodes interethnic relationships and leads to physical extermination known as genocide. (Beltrão 2013: 10)
} 


\section{References}

ALMEIDA, A.W. B. 2008. Terra de quilombo, terras indígenas, "babaçuais livre", "castanhais do povo", faixinais e fundos de pasto: terras tradicionalmente ocupadas. 2. e. ed. Manaus: Pgsca-Ufam.

ALMEIDA, A. W. B.; GAYOSO, S.; MILEO, B. P.; VIEIRA, J. C.; VIEIRA, J. C.; LIMA, M. V. C. 2015. Mapeamento social dos povos e comunidades tradicionais do rio Tapajós: povo Munduruku e a luta pelo reconhecimento do território. Manaus: UEA-Edições. v. 1.16 p.

AMSELLE, Jean-Loup. 2001. Branchements: anthropologie de l'universalité des cultures. Paris: Flamarion.

ASAD, Talal. 1991. "Afterword: from the history of colonial anthropology to the anthropology of western hegemony". In: George W. Stocking Jr. (org.), Colonial Situations: Essays on the Contextualization of Ethnographic Knowledge. History of anthropology. Volume 7. Wisconsin: The University of Wisconsin Press. pp. 314-324.

. 1993. "Introduction". In: Genealogies of religion: discipline and reasons of power in Christianity and Islam. Baltimore and London: The Johns Hopkins University Press. pp. 1-24.

BARTH, Fredrik. 1989. Cosmologies in the making. Cambridge: University Press.

BAZIN, Jean. 2017. “A cada um o seu Bambara”. In: Jean-Loup Amselle;, Elikia M’Bokolo (eds.), No centro da etnia: etnias, tribalismo e Estado na África. Petrópolis: Vozes. pp. 119-167.

BENSA, Alban. 1998. “Da Micro-história a uma Antropologia Crítica”. In: Jacques Revel (org.), Jogos de escalas: a experiência da microanálise. Rio de Janeiro: Editora Fundação Getúlio Vargas, pp. 39-76

BELTRÃO, J. F. 2013. "Pertenças, territórios e fronteiras entre os povos indígenas dos rios Tapajós e Arapiuns versus o Estado brasileiro". Antares: Letras e Humanidades, 5(10). http://www.ucs.br/etc/revistas/index.php/ antares/article/view/2544. Accessed on: January o8 2019

DEL ARCO, Diego Pérez. 2017. As comunidades quilombolas de Santarém/PA e o Porto de Maicá: os efeitos sociais de um empreendimento anunciado. Trabalho de Conclusão de Curso de Graduação em Antropologia da Universidade Federal Fluminense. Instituto de Ciências Humanas e Filosofia, Niterói.

DUPRAT, Deborah. 2012. “Comentário jurídico. Direitos Territoriais”. In: Antonio Carlos de Souza Lima (org.), Antropologia e Direito: temas antropológicos para estudos jurídicos. Rio de Janeiro/Brasília: Contra Capa/LACED/ABA, pp. 391-394.

ERIKSEN, Thomas Hylland. 2010. Ethnicity and nationalism. London and New York: Pluto Press. . 2001. Social identity, intergroup conflict, and conflict reduction. Oxford: Oxford University Press.

FABIAN, Johannes. 2010. "Memórias da memória: uma história antropológica”. In: Daniel Aarão Reis et al. (orgs.), Tradições e Modernidades. Rio de Janeiro: FGV. pp. 13-28.

FASSIN, Didier. 2010. La raison humanitaire: une histoire morale du temps present. Paris: Seuil/ Gallimard. FIGUEIREDO, Carla Janaína. 2011. "O falante nativo de inglês versus o falante não-nativo: representações e percepções em uma sala de aula de inglês”. Revista Linguagem \&Ensino, 14(1): 67-92, jan./jun. 2011. Available at: https://periodicos.ufpel.edu.br/ojs2/index.php/rle/article/view/15382. Accessed on: 102019

HARRIS, Mark. 2017. Rebelião na Amazônia: Cabanagem, raça e cultura popular no norte do Brasil, 1798-1840. Campinas: Editora da Unicamp.

HORNE, Gerald. 2010. O Sul mais distante: Os Estados Unidos, o Brasil e o tráfico de escravos africanos. São Paulo: Companhia das Letras.

IORIS, Edviges Marta. 2019. "Chamado do Pajé: regimes de memória, apagamentos e protagonismo indígena no baixo Tapajós." Revista Ciências da Sociedade (RCS), 3(5):39-6o, Jan/Jun 2019. Available at: http://www. ufopa.edu.br/portaldeperiodicos/index.php/revistacienciasdasociedade/article/view/984/510. Accessed on: September 10, 2019. . 2014. Uma Floresta de disputas: conflitos sobre espaços, recursos e identidades sociais na Amazônia. Florianópolis: Ed. da UFSC. 
2018. "Memory regimes, struggles over resources and ethnogenesis in the Brazilian Amazon".

Vibrant, Virtual Braz. Anthr., 15(2). Available at: http://www.scielo.br/scielo.php?script=sci_ arttext\&pid=S1809-43412018000200405\&lng=pt\&nrm=iso . Accessed on September 292019.

LAGO, I. J. 2017. "Revisitando os conceitos básicos da disciplina jurídica do parcelamento do solo urbano". Reju - Revista Jurídica, 4(1). http://oapecsuperior.com.br/revista-cientifica/index.php/REJU/article/ view/59/81. Accessed on: June og 2019

LIMA, Leandro Mahalem de. 2015. No Arapiuns, entre verdadeiros e -ranas: sobre os espaços, as lógicas, as organizações e os movimentos do político. Tese de Doutorado. Faculdade de Filosofia, Letras e Ciências Humanas. Universidade de São Paulo.

. 2019. "Pajelança nas adjacências do Rio Amazonas: dimensões sociopolíticas e cosmológicas". Revista Ciências da Sociedade (RCS), 3(5): 61-91, Jan/Jun 2019. Available at: http://www.ufopa.edu.br/ portaldeperiodicos/index.php/revistacienciasdasociedade/article/view/985 . Accessed on: September 10 2019.

LOURES, Rosamaria. 2018. "The Karodaybi Government and its Invincible Warriors: the Munduruku Ipereğ Ayũ Movement versus large construction projects in the Amazon”. Vibrant, Virtual Braz. Anthr., 15(2). Available at: http://www.scielo.br/scielo.php?script=sci_arttext\&pid=S1809-43412018000200404\&lng=pt \&nrm=iso\&tlng=en . Accessed on: September 29, 2019.

O'DWYER, Eliane Cantarino. 2000. "Damatta nas paradas entre 'malandros' ou 'heróis': a lenda da cobragrande, o tempo histórico e questões de identidade". In: Laura Graziela Gomes et al. (orgs.), O Brasil não é para principiantes: Carnavais, malandros e heróis 20 anos depois. Rio de Janeiro: Editora FGV. pp.185220.

. 2013. "Desenvolvimento e Povos Tradicionais". In: Anete B. L. Ivo; Elsa Kraychete; Ângela Borges; Cristiana Mercuri; Denise Vitale; Stella Senes (orgs.), Dicionário Temático Desenvolvimento e Questão Social. 1a ed. São Paulo: ANNABLUME Editora. pp. 123-128.

2016. "Uma nova forma de fazer história: os direitos às terras de quilombo diante do projeto modernizador de construção da Nação". In: Osvaldo Martins de Oliveira (org.), Direitos quilombolas \& dever de Estado em 25 anos da Constituição Federal de 1988. Rio de Janeiro: Associação Brasileira de Antropologia, pp. 257-273.

. et ali. 2011. Relatório Antropológico de Identificação e Delimitação das Comunidades Remanescentes de Quilombo do Território Maria Valentina. Santarém: INCRA.

OLIVEIRA, João Pacheco de. 1998. Uma etnologia dos "índios misturados"? Situação colonial, territorialização e fluxos culturais. Mana, vol.4, n.1, pp.47-77. Available from: http://www.scielo.br/scielo. php?script=sci_arttext\&pid=S0104-93131998000100003\&lng=en\&nrm=iso Accessed on: August 152018.

. 2012. "Terras índígenas". In: A. C. S. Lima (org.), Antropologia e direito: temas antropológicos para estudos jurídicos. Brasília: Rio de Janeiro / Blumenau: Associação Brasileira de Antropologia / Laced / Nova Letra . 2013. "Etnografia enquanto compartilhamento e comunicação; desafios atuais às representações coloniais". In: Bela Feldman-Bianco (org.), Desafios da Antropologia Brasileira. 1르 ed. Brasilia: ABA Publicações. v. 1. pp. 47-74.

OLIVEIRA, Luís R. Cardoso de. 1996. "Besta-Fera: recriação do mundo. Ensaios de crítica antropológica. Mana [online], 2(2): 205-208. Available at em: <http:|/www.scielo.br/scielo.php?script=sci_ arttext\&pid=S0104-93131996000200015\&lng=en\&nrm=iso >. Accessed on: January 10, 2019.

PALMEIRA, Moacir. 1989. "Modernização, Estado e questão agrária”. Estudos Avançados, 3(7). São Paulo Sept./ Dec. Available at: http:/|www.scielo.br/scielo.php?script=sci_arttext\&pid=S0103-40141989000300006.

Accessed on September 20 2019. https://doi.org/10.116o6/issn.2176-7793.v39i2p87-269

PAPAVERO, N.; OVERAL, W. (orgs.). 2011. Taperinha. Belém: Ed. Museu Paraense Emílio Goeldi. 
PAPAVERO, N., OVERAL, W., TEXEIRA, D., \& HINSHAW, J. 2008. "The travels of Joseph Beal Steere in Brazil, Peru and Ecuador (1870-1873)". Arquivos de Zoologia, 39(2): 87-269.

PEREIRA. Deborah Duprat de Britto. 2002. “O Estado pluriétnico”. In: Antônio Carlos Souza Lima; Maria Barroso-Hoffmann (orgs.), Além da tutela: bases para uma nova Política Indigenista III. Rio de Janeiro: Contra-Capa.

QUIJANO, Aníbal. 2005. “Colonialidade do poder, Eurocentrismo e América Latina”. In: A colonialidade do saber: eurocentrismo e ciências sociais. Perspectivas latino-americanas. Buenos Aires: CLACSO, Consejo Latinoamericano de Ciencias Sociales. Available at: http://biblioteca.clacso.edu.ar/clacso/sursur/20100624103322/12_Quijano.pdf. Accessed on: August 10, 2018.

SALLES, Vicente. 1971. O negro no Pará sob o regime de escravidão. Rio de Janeiro: FGV/UFPA.

SILVA, Célio Antonio Alcântara. 2011. Capitalismo e escravidão: a imigração Confederada para o Brasil. Tese de Doutorado. Instituto de Economia da UNICAMP, Campinas.

SMITH, H. H. 1879. Brazil: The Amazons and the Coast. New York: Charles Scribnr's Sons.

VAN DER VEER, Peter. 2001. Imperial Encounters: Religion and Modernity in India and Britain. Princeton: Princeton University Press.

VAZ FILHO, Florêncio Almeida. 2010. A emergência étnica de povos indígenas no Baixo Tapajós. Tese de Doutorado. Programa de Pós-Graduação em Ciências Sociais - PPGCS/UFBA, Salvador. . 2013. Os conflitos ligados à sobreposição entre terras indígenas e a resex Tapajós-Arapiuns no Pará. RURIS - Revista do Centro de Estudos Rurais - UNICAMP, 7(2), pp. 143-183. Available at: https:||www.ifch. unicamp.br/ojs/index.php/ruris/article/view/1886. Accessed on: August 152019.

VELHO, Otávio. 1995. Besta-Fera: Recriação do Mundo. Ensaios de Crítica Antropológica. Rio de Janeiro: RelumeDumará.

\section{Documents consulted:}

IACHR - Inter-American Commission on Human Rights. 2018. Observações preliminares da visita in loco da CIDH ao Brasil. Available at: https://www.oas.org/es/cidh/prensa/comunicados/2018/238OPport.pdf Accessed on: November 152018.

MINISTÉRIO PÚBLICO FEDERAL - MPF. Ação Civil Pública com pedido de tutela provisória de urgência. Santarém, 2018. Available at: http://www.mpf.mp.br/pa/sala-de-imprensa/documentos/2018/acao_ mpf_identificacao_delimitacao_territorio_munduruku_planalto_santareno_pa_maio_2018.pdf/view. Accessed on June 152018. 


\section{News from newspapers and websites}

GRIM, Ryan. Steve Schwarzman, apoiador de donald trump, impulsiona o desmatamento na amazônia. 28 de Agosto de 2019. Available at: https://theintercept.com/2019/08/28/steve-schwarzman-apoiador-dedonald-trump-impulsiona-o-desmatamento-na-amazonia|. Accessed on August 302019.

MATIAS, Ivaci. Grupo usou whatsapp para convocar "dia do fogo" no Pará: polícia investiga ação de incendiários, ao menos 70 pessoas participaram de grupo de mensagens; no dia 10 de agosto, número de focos de incêndios cresceu repentinamente na Amazônia. Cachoeira da Serra (PA), 25 de Agosto de 2019. Available at: https:|/revistagloborural.globo.com/Noticias/noticia/2019/o8/grupo-usou-whatsapp-paraconvocar-dia-do-fogo-no-para.html. Accessed on August 302019.

Eliane Cantarino O'Dwyer

Federal Fluminense University (UFF) Retired Full Professor

Federal University of Pará (UFPA) Senior Visiting Professor

https://orcid.org/0000-0003-0523-188X

Email: elianeantropologia@gmail.com

Katiane Silva

Federal University of Pará (UFPA) Professor

https://orcid.org/oooo-0002-1938-9373

Email: katiane.mars@gmail.com 